\title{
HUBUNGAN ANTARA KEBERMAKNAAN KERJA DENGAN KOMITMEN ORGANISASI
}

\author{
Abraham Irianto ${ }^{1}$, Berta Esti Ari Prasetya ${ }^{2}$ \\ Fakultas Psikologi, Universitas Kristen Satya Wacana \\ Jalan Diponegoro No 52 - 60 Salatiga 50711 1,2 \\ Email:802015002@student.uksw.edu ${ }^{1}$
}

\begin{abstract}
This research aimed to knew the relationship between meaningful work and organizational commitment. The participants of this study consisted of 52 partisipants. The hypothesis in this research was the existence of a positive significant relation between meaningful work and organizational commitment. Measurement instruments in this research was a Work and Meaning Inventory by Steger, Dik, and Duffy (2012) and Organizational Commitment Questionnaire by Meyer and Allen (1990). Data analysis technique used Product Moment Correlation by Karl Pearson and helped by SPSS ver 16.00 for Windows. The result in this research found there was a positive and significance correlation between meaningful work and organizational commitment that $r=0,442$ with a significance of $p=0,001(P<0,005)$ which meant with higher meaningful work, the organizatinal commitment would be high. Otherwise with lower meaningful work, organizational commitment would be low.
\end{abstract}

Keywords: Kebermaknaan Kerja, Komitmen Organisasi.

\section{Abstrak}

Penelitian ini bertujuan untuk mengetahui hubungan antara kebermaknaan kerja dengan komitmen organisasi. Hipotesis dalam penelitian ini adalah adanya hubungan yang positif antara kebermaknaan kerja dengan komitmen organisasi. Subjek dalam penelitian ini sebanyak 52 partisipan. Alat ukur yang digunakan adalah Skala Kebermaknaan Kerja dari (Steger et al., 2012) dan Skala Komitmen Organisasi dari (Meyer dan Allen 1990). Data yang terkumpul diolah dengan uji korelasi Pearson Product Momentdan dibantu dengan program SPSS ver16,00 for windows. Hasil uji hipotesis menunjukkan bahwa adanya hubungan yang positif dan signifikan antara kebermaknaan kerja dengan komitmen organisasi dengan nilai $r=0,442$ dan $p$ $=0,001(p<0,005)$ artinya apabila karyawan memiliki nilai makna kerja yang semakin tinggi maka semakin tinggi komitmen organisasinya begitu juga bila karyawan memiliki nilai makna kerja yang semakin rendah maka semakin rendah komitmen organisasinya.

Kata Kunci: Menaingful Work, Organizational Commitment

\section{PENDAHULUAN}

Perkembangan teknologi memberi keuntungan bagi banyak pihak, misalnya kemudahan dalam mendapatkan informasi. Contohnya adalah informasi lowongan pekerjaan yang semakin mudah didapatkan, seperti melalui Google, dan situs pencari kerja yang semakin banyak. Orang-orang yang memiliki akun pencari kerja memiliki pertumbuhan tiap tahunnya, seperti yang telah ditulis Tribbunnews Makassar (2017) bahwa situs pencari kerja Jobstreet mengalami peningkatan akun pencari kerja lebih dari sepuluh ribu. Kemudahan ini mendorong setiap orang untuk dapat mengakses informasi mengenai lowongan pekerjaan yang mereka minati. Fenomena MEA (Masyarakat Ekonomi Asean) juga memberi peluang tenaga kerja untuk bekerja lintas negara dalam lingkup ASEAN. Katadata (2016) menulils laporan dari Badan Pusat Statistik bahwa ada warga negara asing (WNA) yang 
berkunjung ke Indonesia kurang lebih satu tahun untuk tujuan bekerja paruh waktu mencapai 25 ribu orang. Fenomena kebebasan bekerja dalam lingkup ASEAN menuntut karyawan untuk memberi kinerja terbaiknya karena bisa saja tergantikan oleh pelamar yang lebih baik.

Bagi perusahaan ada salah satu kesulitan yaitu mempertahankan karyawan-karyawannya demi tercapainya tujuan perusahaan. Hal ini sejalan dengan penjelasan Kanter (2001) bahwa tantangan terbesar bagi perusahaanperusahaan di budaya elektronik (eculture) adalah mencari dan mempertahankan orang terbaik dan bagaimana mereka mampu memenuhi tantangan global pada saat loyalitas menurun. Persaingan bisnis yang diikuti dengan perkembangan teknologi membuat menuntut setiap karyawan memiliki kompetensi yang tinggi. Hal ini sejalan dengan pendapat yang dijelaskan oleh Rani (2016) bahwa perbedaan antara kemampuan yang dibutuhkan dan kemampuan yang dimiliki pelamar menyebabkan perusahaan merekrut pelamar dari perusahaan lain karena rendahnya sumber daya manusia yang sesuai dengan kebutuhan perusahaan. Penjelasan tersebut menggambarkan pentingnya komitmen organisasi.

Menurut Meyer dan Allen (1990) komitmen organisasi merupakan suatu keadaan psikologis yang mengikat kuat individu dalam organisasi. Ada tiga aspek komitmen organisasi yaitu komitmen afektif, komitmen berkelanjutan, dan komitmen normatif. Pertama, komitmen berkelanjutan adalah suatu keadaan dimana faktor untung dan rugi menjadi pertimbangan ketika meninggalkan organisasi, dan komitmen normatif menekankan adanya rasa kewajiban bagi karyawan untuk berkomitmen karena imbalan yang diberikan perusahaan. Salah satu faktor-faktor yang memengaruhi komitmen organisasi menurut Dyne dan Graham (1994) adalah faktor situasional. Faktor situasional meliputi workplace values yaitu nilai-nilai yang dianut dalam tempat kerja, hubungan interpersonal dengan supervisor dan karakteristik pekerjaan. Karakteristik pekerjaan meliputi pekerjaan yang adanya otonomi dan umpan balik dalam pekerjaannya. Menurut Geldenhuys, Laba, dan Venter (2014) otonomi pekerjaan, kepuasan, dan keterlibatan adalah bagian yang membentuk kebermaknaan kerja.

Steger menulis makna kerja adalah pengalaman subyektif individu akan pekerjaannya yang bertujuan dan memberikan dampak yang signifikan. Menurutnya makna kerja memberikan sisi positif bagi seseorang yaitu 
kebermaknaan. Makna kerja bukan bersifat hedonic atau memuaskan diri sendiri tapi bersifat eudaimonic yaitu berpusat pada perkembangan diri dan tujuan. Aspek dari makna kerja menjadi tiga, yaitu: a) positive meaning in work yaitu makna kerja merupakan pengalaman subyektif yaitu apa yang kita lakukan memiliki makna pribadi; b) meaning making through work yaitu makna kerja membantu karyawan memperdalam pemahaman mereka tentang diri sendiri dan dunia di sekitar mereka, serta memfasilitasi pertumbuhan pribadi mereka; c) greater good motivations yaitu kebermaknaan kerja juga berhubungan dengan keinginan untuk membuat dampak positif yang lebih luas.

Menurut Steher, dkk (2012) makna kerja tidak hanya mengenai pekerjaan yang siginifikan bagi karyawan namun juga memiliki dampak yang positif. Bekerja dengan seseorang yang memiliki makna kerja akan menimbulkan pemikiran positif dan konsekuen dalam melihat pekerjaan, sehingga seseorang yag memiliki makna kerja tidak hanya memiliki dampak yang baik bagi dirinya, namun untuk sosial karywan dan bahkan perusahaan tempatnya bekerja. Menurut Geldenhuys (2014) karyawan yang mengalami kebermakaan kerja dan memiliki keinginan untuk memiliki manfaat yang lebih luas menunjukkan kualitas yang diinginkan perusahaan, seperti komitmen organisasi. Chan (2006) dalam penelitiannya menemukan bahwa komitmen yang tinggi dari anggota kelompok akan memberikan energi dan memotivasi mereka untuk bekerja lebih baik. Anggota yang berkomitmen tinggi akan saling menerima, belajar dari anggota yang lain dan berpartisipasi penuh dalam kegiatan organisasi. Sebaliknya Singh dan Bandarker (2006) karyawan yang keluar dan memilih pekerjaan baru karena mereka tidak mengalami kebermaknaan dalam pekerjaan mereka.

Penelitian yang dilakukan Widyastuti dan Nugroho (2017) menemukan bahwa makna kerja memiliki korelasi yang signifikan dan memberi sumbangan efektif sebesar 36,2\% terhadap terciptanya komitmen organisasi. Namun penelitian dari Faisal Rachmat (2009) dalam hubungan antara makna kerja dan kohesivitas kerja tim terhadap komitmen organisasi menemukan bahwa makna kerja tidak memiliki hubungan signifikan terhadap komitmen organisasi. Korelasi dalam penelitian beliau sebesar 0,217. Perbedaan hasil penelitian ini, peneliti ingin kembali meneliti hubungan makna kerja dengan komitmen organisasi. Hipotesis penelitian yang digunakan 
dalam penelitian ini adalah adanya hubungan yang positif dan signifikan antara kebermkanaan kerja dengan komitmen organisasi.

\section{METODE}

Penelitian ini adalah penelitian kuantitatif asosiatif yaitu penelitian yang dirancang untuk menentukan hubungan variabel-variabel yang berbeda dalam suatu populasi. Adapun variabel-variabel yang ada dalam penelitian yaitu kebermaknaan kerja (variabel independen) dan komitmen organisasi (variabel dependen). Definisi konsptual dari komitmen organisasi menurut Meyer dan Allen (1990) adalah karaktristik hubungan antara anggota organisasi dengan organisasinya dan memiliki implikasi terhadap keputusan individu untuk melanjutkan kenaggotaannya dalam berorganisasi. Komitmen Organisasi diukur melalui Organizational Commitment Quesionnaire.

Steger, dkk (2012) menjelaskan pengalaman subjektif individu yang terdiri dari persepsi positif pekerja terhadap pekerjaan dan merasa pekerjaan mampu memfasilitasi pertumbuhan diri serta merasa pekerjaan memberi manfaat yang lebih baik bagi orang lain. Kebermknaan kerja diukur melalui Work and Meaning Inventory.

Penelitian di lakukan di Suzuki
Finance Surakarta. Populasi yang dipilih adalah karyawan staf Suzuki Finance Surakarta. Jumlah sampel yang dibutuhkan adalah 52 karyawan. Teknik pengambilan dalam penelitian ini menggunakan penentuan non-probablity sampling yaitu teknik pengambilan sampel yang memberikan peluang tidak sama pada setiap anggota

populasi. Jenis teknik non-probability yang dipilih adalah sampling jenuh merupakan teknik penentuan sampel dengan menjadikan semua anggota populasi sebagai sampel.

\section{HASIL}

Berdasarkan hasil analisis deskriptif (tabel 1) pada variabel kebermaknaan kerja diperoleh data mean 28,42 dan standar deviasi 3,127.

\begin{tabular}{llllll}
\multicolumn{4}{c}{ Tabel 1. Analisis Deskriptif } \\
\hline & $\mathrm{N}$ & $\begin{array}{c}\text { Minim } \\
\text { um }\end{array}$ & $\begin{array}{l}\text { Maxi } \\
\text { mum }\end{array}$ & $\begin{array}{c}\text { Mean } \\
\text { Deviatio } \\
\mathrm{n}\end{array}$ \\
\hline $\begin{array}{l}\text { Keberma } \\
\text { knaan } \\
\text { Kerja }\end{array}$ & 52 & 23 & 37 & 28.42 & 3.127 \\
\hline $\begin{array}{l}\text { Komitmen } \\
\text { Organisa } \\
\text { si }\end{array}$ & 52 & 21 & 46 & 35.48 & 4.901 \\
\hline $\begin{array}{l}\text { Valid N } \\
\text { (listwise) }\end{array}$ & 52 & & & & \\
\hline
\end{tabular}

Variabel komitmen organisasi pada tabel analisis dekriptif memperoleh nilai mean 35,48 dan standar deviasi 4,901 .

Berdasarkan uji linearitas (tabel 2) 
yang telah dilakukan, menunjukkan bahwa hubungan antara kebermaknaan kerja dengan komitmen organisasi adalah linear, yaitu deviation from linearity sebesar 2,301 dengan signifikansi 0,024 $(\mathrm{p}<0.05)$.

\begin{tabular}{|c|c|c|c|c|c|c|c|}
\hline & & & $\begin{array}{c}\text { Sum of } \\
\text { Square } \\
s\end{array}$ & df & $\begin{array}{c}\text { Mean } \\
\text { Squar } \\
\text { e }\end{array}$ & $\mathrm{F}$ & Sig. \\
\hline \multirow[t]{5}{*}{$\begin{array}{l}\mathrm{KO} \\
{ }^{*} \mathrm{KK}\end{array}$} & \multirow[t]{3}{*}{$\begin{array}{l}\text { Between } \\
\text { Groups }\end{array}$} & (Combined) & $\begin{array}{r}679.96 \\
7 \\
\end{array}$ & 14 & 48.569 & $\begin{array}{r}3.29 \\
7 \\
\end{array}$ & .002 \\
\hline & & Linearity & $\begin{array}{r}239.26 \\
0 \\
\end{array}$ & & $\begin{array}{r}239.26 \\
0 \\
\end{array}$ & $\begin{array}{r}16.2 \\
43 \\
\end{array}$ & .000 \\
\hline & & $\begin{array}{l}\text { Deviation } \\
\text { from } \\
\text { Linearity }\end{array}$ & $\begin{array}{r}440.70 \\
7\end{array}$ & 13 & 33.901 & $\begin{array}{r}2.30 \\
1\end{array}$ & .024 \\
\hline & \multicolumn{2}{|c|}{ Within Groups } & $\begin{array}{r}545.01 \\
3 \\
\end{array}$ & 37 & 14.730 & & \\
\hline & \multicolumn{2}{|l|}{ Total } & $\begin{array}{r}1224.9 \\
81\end{array}$ & 51 & & & \\
\hline
\end{tabular}

Hasil dari uji korelasi (tabel 3) menunjukkan nilai $r=0,442$ dengan nilai signifikansi 0,001 $(\mathrm{p}<0,05)$. Hasil tersebut menunjukkan bahwa ada hubungan positif dan signifikan antara kebermaknaan kerja dengan komitmen organisasi.

\begin{tabular}{llrr}
\hline \multicolumn{4}{c}{ Tabel 3. Uji Hipotesis } \\
\hline \multirow{3}{*}{ KK } & KK & KO \\
\cline { 2 - 4 } & Pearson Correlation & 1 & .442 \\
\cline { 2 - 4 } & Sig. (1-tailed) & 52 & .001 \\
\cline { 2 - 4 } & $\mathrm{N}$ & $.442^{* *}$ & \multicolumn{1}{c}{1} \\
\hline KO & Pearson Correlation & .001 & \\
\cline { 2 - 4 } & Sig. (1-tailed) & 52 & 52 \\
\cline { 2 - 4 } & $\mathrm{N}$ &
\end{tabular}

\section{PEMBAHASAN}

Berdasarkan uji daya diskriminasi aitem yang dilakukan terhadap kedua skala menunjukkan bahwa skala kebermaknaan kerja memiliki 1 aitem yang gugur dengan batas korelasi $\leq 0,3$ sedangkan skala komitmen organisasi memiliki 11 aitem yang gugur dengan batas korelasi $\leq 0,3$. Berdasarkan hasil analisis deskriptif pada variabel kebermaknaan kerja diperoleh data mean 28,42 dan standar deviasi 3,127. Variabel komitmen organisasi pada tabel analisis dekriptif memperoleh nilai mean 35,48 dan standar deviasi 4,901.

Karyawan yang berada pada kategori sangat tinggi memiliki persentase 80,77 persen, kayawan yang berada pada kategori tinggi memiliki persetase 19,23 persen, kemudian karyawan yang berada pada kaetgori rendah memiliki persentase 0 persen dan karyawan yang berada pada kategori sangat rendah pada kategori 0 persen. Berdasarkan mean yang diperoleh, dapat dikatakan bahwa kebermaknaan kerja yang dimiliki karyawan tergolong sangat tinggi.

Tingkat komitmen organisasi yang berbeda-beda. Karyawan yang berada pada kategori sangat tinggi memiliki persentase 17,30 persen, kayawan yang berada pada kategori tinggi memiliki persetase 73,03 persen, kemudian karyawan yang berada pada kaetgori rendah memiliki persentase 7,69 persen dan karyawan yang berada pada kategori sangat rendah pada kategori 1,92 persen. 
Berdasarkan mean yang diperoleh, dapat dikatakan bahwa komitmen organisasi yang dimiliki karyawan tergolong tinggi.

Hasil dari uji korelasi menunjukkan nilai $r=0,442$ dengan nilai signifikansi 0,001 $(\mathrm{p}<0,05)$. Hasil tersebut menunjukkan bahwa ada hubungan positif dan signifikan antara kebermaknaan kerja dengan komitmen organisasi. Hasil tersebut menandakan bahwa terdapat hubungan yang positif dan signifikan antara kebermaknaan kerja dengan komitmen organisasi pada karyawan di PT. Suzuki Finance Surakarta. Hasil penelitan ini senada dengan penelitian yang dilakukan oleh Widyastuti dan Nugroho (2017) bahwa ada hubungan yang positif dan signifikan antara kebermaknaan kerja dengan komitmen organisasi. Hal ini menunjukkan bahwa semakin tinggi kebermaknaan kerja karyawan maka semakin tinggi pula komitmen organisasi.

Salah satu faktor yang memengaruhi komitmen organisasi menurut Steers dna Porter (1983) adalah karakteristik kerja yang didalamnya adalah tantangan kerja, umpan balik, stres kerja, identifikasi tugas, pengembangan diri dan tanggung jawab. Menurut Geldenhuys, dkk (2014) hal-hal ini membentuk kebermaknaan kerja seperti umpan balik, otonomi, keterlibatan dan pengembangan diri merupakan hal yang membentuk kebermaknaan kerja.

Menurut Steger, dkk Kebermaknaan kerja adalah penilaian pribadi individu bahwa pekerjaannya memiliki dampak yang signifikan dan positif. Ia juga menjelaskan bahwa seseorang yang memiliki makna kerja dalam pekerjaannya mampu melihat pekerjaannya lebih luas. Pemaknaan kerja yang positif akan mendorong karyawan memiliki komitmen terhadap organisasi atau perusahaan. Karyawan yang memiliki makna kerja akan membuat dirinya lebih mengenal pekerjaannya, dan menanamkan nilai-nilai dari pekerjaan tersebut ke dalam dirinya, sehingga pekerjaan ini tidak hanya rutinitas namun telah menjadi bagian dari diri seorang karyawan.

Menurut Morin (2008) karyawan yang memiliki penilaian yang positif terhadap pekerjaannya membuat ia bekerja tidak hanya sebagai rutinitas namun juga sebagai pengembangan diri. Karyawan yang memiliki pemaknaan yang positif dalam pekerjaannya, dalam lingkungan kerjanya, dan hubungan kerjanya, maka karyawan tersebut semakin menemukan kebermaknaan dalam pekerjaannya dan merasa sehat secara fisik dan mental. Hasilnya karyawan akan cenderung hadir tepat waktu, berkomitmen terhadap 
pekerjaannya, waspada dalam menjalankan tugasnya dan bekerjasama dengan rekan-rekan kerjanya untuk mencapai tujuan yang telah disepakati dalam organisasi serta bekerja sesuai apa yang diharapkan.

Morin (2008) berpendapat karyawan yang menganggap pekerjaannya negatif, cenderung tidak memaknai pekerjaannya dan memiliki gejala stres. Ia memiliki strategi pertahanan untuk mempertahankan kehadiran, komitmen dan kinerjanya di tempat kerja namun ketika ia tidak bisa mempertahankan hal tersebut hasilnya akan memburuk seperti kehadirannya menurun, hasil pekerjaan yang tidak maksimal, ia memiliki ketidakpuasan dan cenderung memiliki konflik.

Hasil penelitian ini menunjukkan bahwa kebermaknaan kerja memberikan kontribussi sebesar 44,2 persen pada komitmen organisasi. Jadi ada 55,8 persen faktor lain yang memengaruhi karyawan memiliki komitmen organsiasi. Elsewed dan Mohammed (2014) dalam penelitiannya menunjukkan bahwa faktor yang memengaruhi komitmen organisasi adalah kepuasan kerja. Penelitian yang lain, yang dilakukan oleh Beukes dan Bortha (2013) menunjukkan bahwa work engagement adalah faktor yang memengaruhi komitmen organisasi.
Penelitiannya kepada perawat-perawat di Afrika Selatan menunjukkan bahwa adanya korelasi yang positif antara keterlibatan kerja atau work engagement dengan komitmen organisasi.

Karyawan yang menjadikan pekerjaan sebagai bagian dari dirinya memiliki kecenderungan untuk memiliki kedekatan secara emosional. Menurut Park (2014) karyawan secara afektif akan menemukan kecocokan diri dengan nilainilai dari pekerjaan, kemudian karyawan merasa menjadi bagian penting dari organisasi dan ikut mencapai tujuan organisasi. Selain itu karyawan yang memiliki komitmen organisasi cenderung bertahan lebih lama, dengan kata lain dapat menurunkan resiko turnover di perusahaan. Dapat disimpulkan bahwa komitmen organisasi merupakan hal yang penting bagi perusahaan atau organisasi.

$$
\text { Menurut Morin }
$$

meningkatkan kebermaknaan kerja dapat dilakukan dengan mendorong pengembangan hubungan profesional seperti memelihara hubungan yang positif, dan mengembangkan kedekatan dengan rekan kerja sehingga menghasilkan lingkungan kerja yang baik. Manajer harus memastikan hubungan positif ini terjaga dengan cara memberi contoh baik dalam sikap dan perilakunya di tempat kerja seperti mendorong setiap karyawan 
untuk saling menghormati, dan menghargai komitmen karyawan.

\section{KESIMPULAN}

Berdasarkan penelitian yang telah dilakukan tentang hubungan antara kebermaknaan kerja dengan komitmen organisasi pada PT. Suzuki Finance Surakarta maka dapat disimpulkan:

1.Terdapat hubungan atau korelasi yang positif dan signifikan antara kebermaknaan kerja dengan komitmen organisasi. Jadi apabila kebermaknaan kerja karyawan semakin tinggi maka komitmen organisasi karyawan juga tinggi dan sebaliknya apabila kebermaknaan kerja rendah maka komitmen organisasi juga rendah.

2.Tingkat kebermaknaan kerja yang dimiliki karyawan tergolong sangat tinggi, dapat dilihat dengan nilai rata-rata 28,42. Nilai ini mengartikan karyawan memiliki penilaian yang positif terhadap pekerjaannya, melihat pekerjaannya sebagai hal yang meningkatkan tujuan hidup dan melihat bahwa pekerjaannya bermanfaat bagi banyak orang.

3.Tingkat komitmen organisasi yang dimiliki karyawan tergolong tinggi dengan nilai rata-rata 35,48 . Nilai ini artinya karyawan mampu menilai bahwa adanya kecocokan antara tujuan pribadi dengan tujuan organisasi, sehingga karyawan mendukung tujuan yang sudah disepakati dalam organisasi

Saran peneliti bagi perusahaan yaitu: 1) Lebih sering mengingatkan visi dan misi pada karyawan di setiap jabatan. kemudian organisasi/ perusahan pun harus tertib menjalankan misi yang sudah tetapkan; 2) Membangun hubungan antar karyawan yang saling menghormati dalam perusahaan; 3)Memberi kesempatan pada karyawan untuk memberi inovasi, dan melakukan pertukaran ide setiap divisi. Otonomi adalah kunci yang menghubungkan karyawan dan pekerjaannya, serta menumbuhkan rasa kepemilikan produk/ jasa yang diberikan pada konsumen. Saran bagi penelitian selanjutnya yaitu untuk memperbanyak jumlah partisipan penelitian, dan memperhitungkan masa bekerja partisipan, melakukan penelitian terkait dengan faktor-faktor lain yang mendorong komitmen organsiasi seperti kepuasan kerja dan work engagment atau keterlibatan kerja.

\section{DAFTAR PUSTAKA}

Accenture. (2012). The Path Forward: International Women's Day 2012 Global Research Result. Norwegia: Accenture.

Beukes, I., Bortha, E. (2013). Organizational commitment, work engagement, dan meaning of work of nursing staff in hospitals. $S A$ Journal of Industrial Psychology/SA Tydskrif vir 
Bedryfsielkunde. Vol. 39, No. 2, 1 -10 .

Elsewed, M., Mohammed F. (2014). Predicting organizational commitment via job satisfaction, gender, age, experience, and position: An empirical investigation in a private financial institution in Bahrain. International Journal of Business and Social Science. Vol. 5, No. 9, $150-158$.

Geldenhuys, M., Laba, K., Venter, C. M. (2014). Meaningful work, work engagement and organisational commitment. SA Journal of Industrial Psychology/SA Tydskrif vir Bedryfsielkunde. Vol 40, No. 1, 1-10.

Jobstreet. (2014). 73\% Karyawan Tidak Puas dengan Pekerjaan Mereka. Diakses pada tanggal 25 Januari 2019.

https://www.jobstreet.co.id/careerresources/73-karyawan-tidak-puasdengan-pekerjaanmereka/\#.XFfqhrhoTIU.

Meyer J. P., Allen, N. J. (1990). The Measurement and antecedents of affective, continuance and normative commitment to the organization. Journal of Occupational Psychology. Vol 63, $1-18$.

Morin, E. (2008). The meaning of work, mental health, and organizational commitment. Sao Paulo: University de Montreal.

Park, H.Y., Christie, R. L., Sype, G. E. (2014). Organizational Commitment and Turnover Intention in Union and Non-union Firms. Sage Publication. 1 - 11.

Kanter. (2001). Evolve: Succeeding in the Digital Culture Tomorrow.
Boston: Harvard Business School Press.

Katadata. (2016). Mea Berlaku, 25 Ribu Pekerja Asing Serbu Indonesia Selama Januari. Diakses pada tanggal 26 Januari 2019 pukul 19.34.

https://katadata.co.id/berita/2016/0 3/01/mea-berlaku-25-ribu-pekerjaasing-serbu-indonesia-selamajanuari.

Rani, Devika. (2016). Employee poaching : It's ethical issues and legal framework - A case study approach. Business Science International Research Journal. Vol. 4, $68-71$.

Rachmat, Faisal. (2009). Hubungan antara makna kerja dan kohesivitas kerja tim terhadap komitmen organisasi karyawan PT Johnson \& Johnson divisi Jansenn Cilag Indonesia.(Tesis). Yogyakarta : Universitas Gajah Mada.

Singh, P., Jain, A. K., \& Bhandarker, A. (2006). Meaning of work in corporate india - Preliminary findings. Journal of Clinical Nursing. Vol 14, No.8, 90-97.

Steers, R.M., Porter, L.W. (1983). Motivation and Work Behavior. New York: Me Graw-Hill Inc.

Steger, M. F., Dik, J. B., Duffy, D. R. (2012). Measuring Meaningful Work and Meaning Inventory (WAMI). Journal of Career Assessment, Vol 00, No. 0, $1-6$.

Tribunnews Makassar. (2017). Lima Tahun, 82 Ribu Pengangguran Ditampung Jobstreet. Diakses pada tanggal 26 Januari 2019 pukul 19.34 . http://makassar.tribunnews.com/20 17/04/20/lima-tahun-82-ribu- 
pengangguran-ditampung-

jobstreet.

Widyastuti, Endang., Nugroho, Yustinus

J. D. (2017). Komitmen Organisasi

Ditinjau Dari Kepuasan Kerja dan

Makna Kerja. Jurnal

Psikohumanika. Vol 9, No.1, 37 49. 